\title{
Polypharmacy, Adverse Drug Reactions and Drug-Drug Interactions in COVID-19-Aging Patients: Considerations on the Clinical Picture
}

\author{
Marileia Chaves Andrade ${ }^{1,2}$ \\ José Henrique Pereira Pinto ${ }^{3}$
}

\section{INTRODUCTION}

\section{Dear Editor,}

Since the beginning of the Coronavirus Disease 2019 (COVID-19) pandemic in March 2020, the etiologic agent of severe acute respiratory syndrome coronavirus 2 (SARS$\mathrm{CoV}-2$ ) has spread across the planet, infecting millions of people of any age range and causing more severe symptoms in elderly individuals with comorbidities such as hypertension, diabetes mellitus, neoplasms, among others1, with a higher risk of complications. In critical clinical conditions, in addition to severe pneumonia, patients have systemic cardiac and hematological complications with the presentation of hypercoagulemia.

It is necessary to consider that the aging of the population is associated with an increase in the prevalence of chronic diseases and the use of more than four drugs regularly, described as polypharmacy. In Brazil, approximately $70 \%$ of older adults have at least one

\footnotetext{
${ }^{1}$ Doutora em Bioquímica e Imunologia pela Universidade Federal de Minas Gerais (UFMG). Professora da Universidade Estadual de Montes Claros (Unimontes). Minas Gerais. Brasil. $\square$ marileia.andrade@unimontes.br_ (iD) https://orcid.org/0000-0002-4496-7331.

${ }^{2}$ Doutora em Bioquímica e Imunologia pela Universidade Federal de Minas Gerais (UFMG). Professora da Faculdade de Medicina de Itajubá (FMIT). Minas Gerais. Brasil. $₫$ marileia.andrade@fmit.edu.br https://orcid.org/0000-0002-4496-7331.

${ }^{3}$ Médico, Faculdade de Medicina de Itajubá (FMIT). Professor Emérito de Alergia e Imunologia, Faculdade de Medicina de Itajubá, (FMIT), Minas Gerais. Brasil, Membro efetivo da Associação Brasileira de Alergia e Imunologia e Organização Mundial de Alergia (WAO) $₫$ jhppinto@yahoo.com.br (D) https://orcid.org/00000002-5401-7946.

$\begin{array}{ccc}\text { Recebido em } & \text { Aceito em } & \text { Publicado em } \\ 26 / 09 / 2020 & 03 / 12 / 2020 & 31 / 12 / 2020\end{array}$
}


chronic disease requiring routine pharmacological treatment 2, and in COVID-19, the sum of complications leads to the use of more drug to symptomatic treatment. To date, there is no drug or therapeutic strategy that is universally recommended with a sufficient level of evidence for COVID-19.

Prescribed drugs, which are already part of geriatric care, associated with the experimental therapeutic drugs of COVID-19, may increase the risk of undesirable occurrences. With aging, physiological changes in pharmacokinetics and pharmacodynamics associated with the large number of drugs ingested, increases the risk of undesirable drug interactions and adverse events that can worsen the clinical picture 3 . This, associated with the uncontrolled inflammation and cytokine storm, so evident in severe cases of COVID-194, compromises the general condition of the elderly patient, decreasing the effectiveness of regular drugs, increasing the risk of death, and impacting the health system by the increase in hospitalization costs 5 .

In times of the new Coronavirus pandemic, epidemiological data show the increase in infection and the development of severe cases of COVID-19 in the elderly population $>65$ years 6 are related to increased mortality risk, in addition to the imminent possibility of collapse of health systems, leading to a greater need for surveillance and appropriate drug management.

Even with the absence of scientific evidence regarding its effectiveness overriding risks, in some countries Chloroquine/Hydroxychloroquine is used for the treatment of hospitalized patients confirmed with COVID-19, and also used in different stages of the disease7. So far, the main risk of drug-drug interactions (DDI) related to the use of Hydroxychloroquine is related to the increase in the QT interval8. In a recent study published by Roos and colleagues9, the authors reinforce the importance of appropriate prescription of drugs when analyzing a cohort of 1001 elderly patients with COVID-19 with polypharmacy and use of Hydroxychloroquine, with the possibility of emergence of inappropriate adverse events and drug interactions (DDI), highlighting the importance of careful monitoring. In patients with COVID-19, to prevent the worsening of the clinical picture caused by secondary bacterial infections (Mycoplasma, Legionella, Chlamydia and others), the antibiotic Azithromycin is frequently used, and a study has shown that in association with Hydroxychloroquine it appears to increase the risk of cardiac change10. It is still important to consider that systemic adverse drug events can increase the severity of the condition, reinforcing polypharmacy and the risk of DDI. For example, the oral use of 
hydroxychloroquine can cause maculopathies and retinopathies, irritability, anxiety, among others. The use of tocilizumab has been associated with an increased risk of fungal and bacterial infections.

In summary, elderly patients with COVID-19 need even more rigorous monitoring due to polypharmacy with regard to the surveillance of occurrences of adverse events and drug interactions, which can increase the risk of worsening the clinical picture, impairment of the general condition, intensification of inflammation and associated unfavorable conditions, incurring the highest probability of mortality.

\section{DECLARATION OF COMPETING INTEREST}

The author declares no competing financial interests or personal relationships that could have appeared to influence the work reported in this paper.

\section{ACKNOWLEDGMENT}

FAPEMIG (Minas Gerais State Research Foundation, Minas Gerais, Brazil); CAPES (Coordination of Training of Higher Education Graduate Foundation, Brasilia, Brazil); and CNPq (National Council for Scientific and Technological Development, Brazil).

\section{REFERENCES}

1 ZHOU Fei; YU Ting, DU Ronghui, et al. Clinical course and risk factors for mortality of adult inpatients with COVID-19 in Wuhan, China: a retrospective cohort study. Lancet, v. 28, 395(10229), p.1054-1062, 2020. Epub 2020 Mar 11. Erratum in: Lancet. 2020 Mar 28;395(10229):1038. Erratum in: Lancet. 2020 Mar 28;395(10229):1038.

2 OLIVEIRA Marcus Vinícius Palmeira; BUARQUE David Costa. Polypharmacy and the use of potentially inappropriate medications among aged in patients. Geriatrics, Gerontology and Aging, v.12, n.1, p.38-44, 2018.

3 BENNETT Alexander; GNJIDIC Danijela; GILLETT Mark, et al. Prevalence and impact of fall-risk-increasing drugs, polypharmacy, and drug-drug interactions in robust versus frail hospitalised falls patients: a prospective cohort study. Drugs Aging, v.31, n.3, p.225-232, 2014.

4 HU Biying; HUANG Shaoying; YIN Lianghong. The cytokine storm and COVID-19. Journal of Medical Virology, v.27, 10.1002/jmv.26232, 2020. 
5 ISIDORO-GARCIA Maria; SANCHEZ-MARTIN Almudena, GARCIA-BERROCAL Belén, et al. Primun non nocere, polypharmacy and pharmacogenetics.

Pharmacogenomics, v16, n.17, p.1903-1905, 2015.

6 McCREARY Erin K, POGUE Jason M. Coronavirus Disease 2019 Treatment: A Review of Early and Emerging Options. Open Forum Infectious Diseases, v.7, n.4, ofaa105, 2020.

7 GELERIS Joshua; SUN Yifei; PLATT Jonathan, et al. Observational Study of Hydroxychloroquine in Hospitalized Patients with Covid-19. The New England Journal of Medicine, v.382, n.18, p.2411-2418, 2020.

8 LEMAITRE Caroline Solas Florian; GRÉGOIRE Matthieu; LAGARCE Laurence, et al. Potential drug-drug interactions associated with drugs currently proposed for COVID-19 treatment in patients receiving other treatments. Fundamental \& Clinical Pharmacology, v.34, n.5, p.530-547, 2020.

9 ROSS Sydney B; WILSON Marnie Goodwin, PAPILLON-FERLAND Louise, et al. COVID-SAFER: Deprescribing Guidance for Hydroxychloroquine Drug Interactions in Older Adults. Journal of the American Geriatrics Society, v.68, n.8, p.1636-1646, 2020.

10 LANE Jennifer CE; WEAVER James; KOSTKA Kristin, et al. Safety of hydroxychloroquine, alone and in combination with azithromycin, in light of rapid widespread use for COVID-19: a multinational, network cohort and self- controlled case series study. MedRxiv preprint, May 31, p:1-29, 2020. 